\title{
The isolation of histidine tRNA from Thermus thermophilus and the study of its primary structure and interaction sites with homologous aminoacyl-tRNA synthetase
}

\author{
O.I. Gudzera, I.A. Krikliviy, A.D. Yaremchuk, M.A. Tukalo
}

The Institute of Molecular Biology and Genetics, NAS of Ukraine 150, Academician Zabolotny Str., Kyiv, 03143, Ukraine

mtukalo@imbg.org.ua

\begin{abstract}
The structure of histidine $t R N A\left(t R N A^{\text {His }}\right)$ is different from $t R N A$ structures of other amino acids specificities by the presence of an extra nucleotide on the 5 '-end (G-1). To study the molecular mechanism of interaction of $t R N A^{H i s}$ with histidyl-tRNA synthetase the purification method of T.thermophilus $t R N A^{H i s}$ was elaborated and the primary structure of isoacceptor form of $t R N A_{1}^{\text {His }}$ was studied. Individual $t R N A^{\text {His }}$ was isolated from the crude $t R N A$, using the combination of low pressure chromatography on benzoyl-DEAE-cellulose (BD-cellulose) and DEAE Toyopearl 650 with high pressure liquid chromatography on DEAE 5PW and Ultrapore C8 columns. The primary structure of T.thermophilus $t R N A_{1}^{\text {His }}$ was determined using the method of rapid gel-sequencing. The studied structure is different from Escherichia coli $t R N A^{\text {His }}$ in 23 positions. The interaction sites of T.thermophilus $t R N A^{H i s}$ with histidyl-tRNA synthetase were investigated using the method of chemical modification by ethylnitrosourea. It was shown that histidyl-tRNA synthetase protects the following phosphates of $t R N A^{\text {His }}$ from alkylation by ethylnitrosourea: 8 - between acceptor and D-stem; 27, 28, 29 -from 5'-side of anticodon stem; phosphate 34 in anticodon and phosphates 67, 68 from 3'-side of acceptor stem. All the revealed sites of $t R N A^{\text {His }}$ are localized on one side of three-dimensional structure of tRNA in the same one where the variable stem side is. D-stem is located on the opposite side and does not interact with the enzyme.
\end{abstract}

Key words: $t R N A$, aminoacyl-tRNA synthetase, RNA-protein recognition, chemical modification

Introduction. The fidelity of protein biosynthesis depends on correct aminoacylation of tRNA by aminoacids. This reaction is catalyzed by aminoacyl-tRNA synthetases which recognize the

(C) O.I. GUDZERA, I.A. KRIKLIVIY, A.D. YAREMCHUK, M.A. TUKALO, 2006 aminoacid and tRNA specifically. At present there is considerable progress in solving the problem of how aminoacyl-tRNA synthetase can specifically recognize cognate tRNAs from a pool of various tRNA species sharing a similar tetriary structure $[1,2]$. Histidine tRNA is unique in possessing an extra nucleotide G-1 at the 5'-end, which forms the additional base-pair 
with the discriminatory residue 73 , thus the acceptor stem of tRNA ${ }^{\text {His }}$ is one nucleotide base-pair longer than other tRNAs. tRNA ${ }^{\text {His }}$ of prokaryotes and organelles have $\mathrm{C} 73$ as their discriminator base, while eukaryotes have A73 and G73 [3].

The study of aminoacylation of Escherichia coli tRNA $^{\text {His }}$ transcripts in vitro proved that the G1 - C73 base-pair is the most important determinant of the recognition by histidyl-tRNA synthetase, while anticodon plays a less expressed role [4]. Contrariwise, the investigation of aminoacylation of tRNA transcripts from yeast proved that the contribution of anticodon into tRNA recognition by histidyl-tRNA synthetase is bigger in comparison with the role of discriminatory basis [5]. At present the crystals of E.coli and T.thermophilus tRNA synthetase complexes are obtained with low molecular substrates - histidine and histidyl - adenylate, using the X-ray structural analysis their structure is determined, and the mechanism of histidine activation is suggested [6-9]. On the basis of charges distribution investigation on the surface of T.thermophilus histidyl-tRNA synthetase and the comparison of these results with the data for other aminoacyl-tRNA synthetases of IIa class, the model of tRNA recognition by enzyme is suggested [8]. Also the crystals of tRNA ${ }^{\text {His }}$ complex with T.thermophilus histidyl-tRNA synthetase were obtained [7], but the structure of this complex was not defined yet. Thus, the study of tRNA ${ }^{\text {His }}$ interaction with histidyl-tRNA synthetase in the solution is of significant interest.

This work describes the isolation of T.thermophilus tRNA $^{\text {His }}$, the definition of its primary structure and the study of interaction sites with histidyl-tRNA synthetase in the solution.

Materials and Methods. The following materials were used in the work: $\left[\alpha-{ }^{32} \mathrm{P}\right] \mathrm{ATP},\left[\gamma-{ }^{32} \mathrm{P}\right] \mathrm{ATP}$, $\left[5^{\prime}-{ }^{32} \mathrm{P}\right] \mathrm{pCp}$ with specific activity of 2000-3000 $\mathrm{Cu} / \mathrm{mmol}$ ("Amersham", UK); T1-ribonuclease from Aspergillus orizae ("Sankyo", Japan); alkaline phosphatase E.coli ("Worthington", USA); T4-polynucleotidekinase ("Boheringer", Germany); nuclease P1 from Penicillium citrinum ("Calbiochem", USA); ribonuclease VI from cobra venom, PhyM from P.polycephalum, U2 from Usilago sphaerogena, CL3 from chicken liver, ribonuclease from Bacillus cereus ("Pharmacia" production, Sweden). Ethylnitrosourea was synthesized by A.G. Terentiev (IMBG of NAS of Ukraine).

The cells of extreme thermophile T.thermophilus HB-27 were grown in the fermenter with the volume of 300 liters in the medium, containing peptone $(2 \%)$, yeast extract $(1 \%)$ and $\mathrm{NaCl}(0.2 \%)$ at the temperature of $74-76^{\circ} \mathrm{C}$ and intensive aeration with the speed of 200 rpm. The cells were collected by centrifugation.

Crude tRNA was obtained by phenol extraction of RNA from the biomass with the subsequent deproteinization by mixtures of phenol:chlorophorm (1:1) and chlorophorm:isoamyl alcohol (9:1) [10]. To purify the RNA from proteins and contaminations of nucleotide and polysaccharide nature, chromatography was used on DEAE-cellulose, equilibrated by $0.0125 \mathrm{M}$ tris- $\mathrm{HCl}, \mathrm{pH}$ 7.5. At first, the contaminations were eluated by $0.15 \mathrm{M} \mathrm{NaCl}$, and then by $0.25 \mathrm{M} \mathrm{NaCl}$ in the same buffer, tRNA from the column was eluated by $1 \mathrm{M} \mathrm{NaCl}$, precipitated by 2.5 of the volume of cooled ethanol in the presence of $2 \%$ of potassium acetate. The sediment of tRNA was collected by centrifugation, then washed by $70 \%$ etanol and dried.

The individual tRNA ${ }^{\mathrm{His}}$ was isolated from crude tRNA, using chromatography on benzoyl-DEAE-cellulose (BD-cellulose), DEAE Toyopearl 650 and high pressure liquid chromatography (HPLC) on the columns of DEAE 5PW and Ultrapore C8 ("Gold System" equipment of "Beckman" company, USA).

T. thermophilus histidyl-tRNAsynthetase was obtained in the homogeneous state using the method described before [7].

The acceptor activity of tRNA ${ }^{\text {His }}$ on different stages of purification was defined according to the maximum level of forming ${ }^{14} \mathrm{C}$-histidyl-tRNA. Standard reaction mixture in the volume of $0.25 \mathrm{ml}$ contained 0.1 tris- $\mathrm{HCl}, \mathrm{pH}$ 7.6, $10 \mathrm{mM} \mathrm{MgCl}, 5 \mathrm{mM}$ ATP, $0.02 \mathrm{mM}$ ${ }^{14} \mathrm{C}$-histidine, $0.4 \mathrm{mg}$ of crude preparation of $T$. thermophilus aminoacyl-tRNA synthetases and 0.05 $\mathrm{ml}$ of the tRNA solution from the investigated fractions. The reaction mixture was incubated for 7 minutes at $65^{\circ} \mathrm{C}$, the reaction was stopped by adding $0.5 \mathrm{ml}$ of cooled $10 \%$ TCA. The sediments of aminoacyl-tRNA were applied to GFC filters, washed by $2 \%$ TCA, dried and the radioactivity was measured by liquid scintillation spectroscopy. 
Labelling of tRNA ${ }^{\text {His }}$ by radioactive phosphorus at 3'- and 5'- ends was accomplished as described in [12, $13,14]$.

The primary structure of $\mathrm{tRNA}^{\mathrm{His}}$ was studied, using two methods of sequencing the labeled tRNA: specific chemical degradation [17] and enzymatic sequencing, based on the hydrolysis of tRNA by specific endonucleases [16, 17].

Enzymatic hydrolysis of $T$. thermophilus tRNAHis was performed for 15 minutes at $55^{\circ} \mathrm{C}$ in $5 \mu \mathrm{l}$ of $20 \mathrm{mM}$ Na-citrate, pH 5.0, 1 mM EDTA, $7 \mathrm{M}$ urea were used for ribonucleases of T1 and PhyM; $20 \mathrm{mM} \mathrm{Na}$-citrate, $\mathrm{pH}$ 3.5, 1 mM EDTA, $7 \mathrm{M}$ urea were used for U2; 20 $\mathrm{mM}$ Na-citrate, $\mathrm{pH}$ 5.0, $1 \mathrm{mM}$ EDTA were used for ribonuclease from B.cereus; $10 \mathrm{mM} \mathrm{Na-phosphate,} \mathrm{pH}$ 6.5 and 4.2 $\mathrm{M}$ urea were used for ribonuclease CL3. tRNA fragments were separated by electrophoresis in $12.5 \%$ and $20 \%$ PAAG in the presence of $8 \mathrm{M}$ urea.

The alkylation of labeled tRNA ${ }^{\text {His }}$ and its complex with histidyl-tRNA synthetase was performed using ethylnitrosourea under conditions, stabilizing three-dimensional structure of tRNA and at the same time favouring the formation of specific complex tRNA $^{\text {His }}$ - histidyl-tRNA synthetase [18]. The reaction mixture in the final volume of $25 \mu \mathrm{l}$ contained $50 \mathrm{mM}$ tris- $\mathrm{HCl}, \quad \mathrm{pH} \quad 7.9, \quad 5 \mathrm{mM} \quad \mathrm{MgCl}_{2}, \quad 2.5 \mathrm{mM}$ 2-mercaptoethanol, $\quad 0.8 \mu \mathrm{M} \quad \mathrm{tRNA}^{\text {His }}, \quad 3.2 \mu \mathrm{M}$ histidyl-tRNA synthetase. Ethylnitrosourea was added to the reaction mixture as a saturated ethanolic solution $(2.5 \mu \mathrm{l})$. In control experiments, pure ethanol was used in place of the ethylnitrosourea solution.

The modification reaction was carried out at $37^{\circ} \mathrm{C}$ for 2 hours and stopped by adding $3 \mu \mathrm{l} 3 \mathrm{M}$ sodium acetate, $\mathrm{pH}$ 5.5. The aminoacyl-tRNA synthetases were removed by phenol extraction and tRNA was precipitated by adding three volumes of ethanol. For more complete precipitation, $10 \mu \mathrm{g}$ of glycogen were added to the mixture.

The alkylation of tRNA under denaturating conditions was performed in $25 \mu 10.3 \mathrm{M} \mathrm{Na}$-cacodylate buffer, $\mathrm{pH} 8.0$, containing $2 \mathrm{mM}$ EDTA at $80^{\circ} \mathrm{C}$ for 2 $\min$.

The cleavage of the polynucleotide chain at the modified residues was carried out by incubation in 10 $\mu 1 \mathrm{0}, 1 \mathrm{M}$ tris- $\mathrm{HCl} \mathrm{pH} 9,0$ at $55^{\circ} \mathrm{C}$ for $5 \mathrm{~min}$. The samples of hydrolyzed tRNA were analyzed by gel- electrophoresis in $12.5 \%$ PAAG in $5 \mathrm{mM}$ tris-borate buffer, $\mathrm{pH} 8.3$, containing $1 \mathrm{mM}$ EDTA and $8 \mathrm{M}$ urine. The electrophoretic bands were assigned by comparison with the T1 -ribonuclease partial digest of tRNAHis. Autoradiograms were scanned on the "UltraScan XL" densitometer ("LKB", Sweden).

Results and Discussion. The isolation of individual $t R N A^{\text {His }}$ from $T$. thermophilus. tRNA ${ }^{\text {His }}$ was isolated from crude tRNA, using the combination of low pressure chromatography on $\mathrm{BD}$-cellulose and DEAE Toyopearl 650 with HPLC on columns DEAE 5PW and Ultrapore C8.

Chromatography on BD-cellulose. $4 \mathrm{~g}$ of crude tRNA from $T$. thermophilus were applied to the BD-cellulose column $(5 \times 60 \mathrm{~cm})$, equilibrated by 50 $\mathrm{mM}$ sodium-acetate buffer, $\mathrm{pH} 4.5$, containing $0.35 \mathrm{M}$ $\mathrm{NaCl}$ and $10 \mathrm{mM} \mathrm{MgCl}_{2}$. Elution was carried out with concave gradient of the $\mathrm{NaCl}$ from $0.45 \mathrm{M}$ (buffer A, 4.0 liter) to $1.5 \mathrm{M}$ (buffer B, 2.0 liter). Concave form of the salt gradient was produced using gradient vials of different diameter $\left(D_{A} / D_{B}=2 / 1\right)$. The application of such a gradient form results in the decrease of the total gradient volume in $40 \%$ and in the corresponding speeding of the process. Moreover, the advantages of this gradient in the comparison with the linear one are in the fact that in the beginning of chromatography, when the main mass of material is eluted from the column, small steep slope of gradient is created, and in the end of chromatography, when "tail" drags on, the gradient becomes steeper and the material is eluted more compactly. $\mathrm{NaCl}$ concentration in the mixer after the output of volume $\mathrm{V}\left(\mathrm{C}_{\mathrm{v}}\right)$ was calculated according to the formula [19].

$$
C_{V}=C_{A}-\left(\left(C_{A}-C_{B}\right) \cdot(1-V) /\left(V_{A}+V_{B}\right)\right)^{\left(S_{A} / S_{B}\right)},
$$

where $C_{A}$ and $C_{B}$-initial concentrations of eluent in the reservoir and mixer; $V_{A}, V_{B}$ - initial volumes of the liquid in vessels; $\quad \mathrm{S}_{\mathrm{A}}, \mathrm{S}_{\mathrm{B}}$ - squares of vessels cross-section.

Elution speed was $120 \mathrm{ml} / \mathrm{h}$ and fractions with volume of $16 \mathrm{ml}$ were collected. After reaching $1.5 \mathrm{M}$ salt concentration the elution was continued with $.5 \mathrm{M}$ $\mathrm{NaCl}$ in $10 \%$ ethanol. Acceptor activity of tRNA for histidine was assayed as described above. Fig.1 presents typical chromatography on BD-cellulose, 


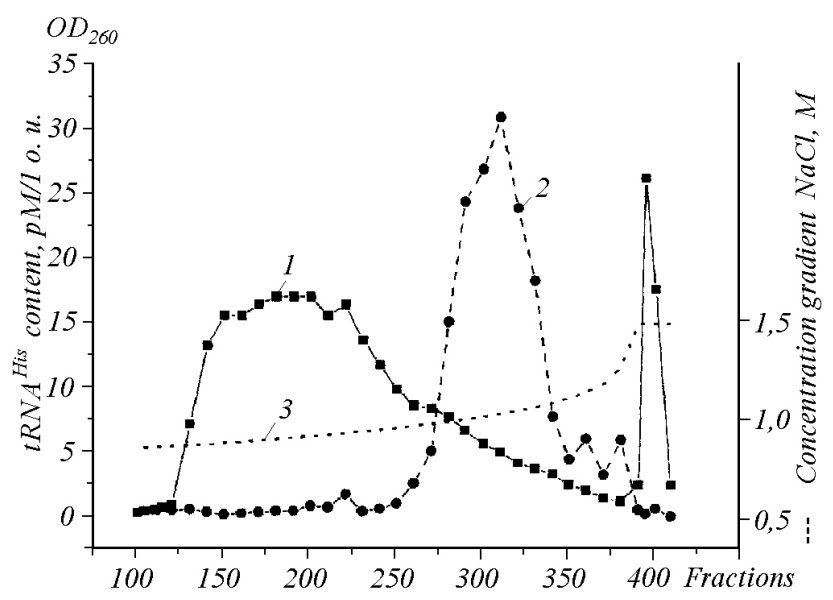

Fig. 1. The chromatography of tRNA from $T$. thermophilus on the column with BD-cellulose: 1 - optic density at $260 \mathrm{~nm} ; 2$ - activity of tRNA ${ }^{\text {His }} ; 3$ gradient of $\mathrm{NaCl}$ concentration.

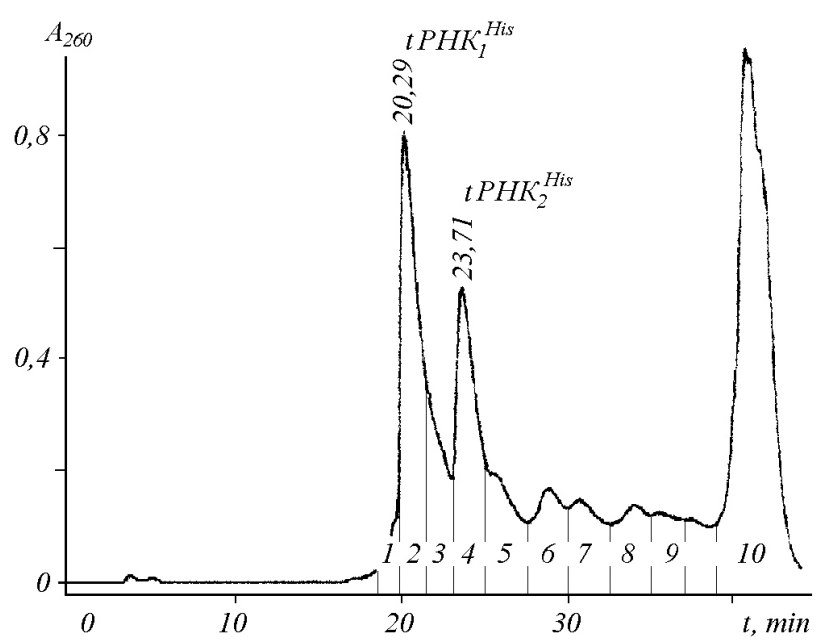

Fig. 2. The purification of tRNA ${ }^{\text {His }}$ from T.thermophilus on the Ultrapore column C8. The vertical lines show the fractions which were collected in the course of chromatography. The output time of tRNA ${ }^{\text {His }}$ from the column is 20.3 minutes (fraction 2, purification degree 95\%) and 23.7 minutes (fraction 4, purification degree $80 \%$ ).

which shows that tRNA ${ }^{\text {His }}$ was found in the fractions 270-340. These fractions were pooled and precipitated with 2.5 volumes of ethyl alcohol, dried and kept at $-20^{\circ} \mathrm{C}$.

Chromatography on DEAE Toyapearl $650.350 \mathrm{mg}$ of tRNA, obtained after the chromatography on BD-cellulose, were applied to the column of DEAE
Toyapearl $650(2.6 \times 25 \mathrm{~cm})$, equilibrated with $10 \mathrm{mM}$ sodium-acetate buffer, $\mathrm{pH} 4.5$, containing $0.2 \mathrm{M} \mathrm{NaCl}$, $10 \mathrm{mM} \mathrm{MgCl}_{2}$ and $10 \%$ isopropanol. Elution was carried out with linear gradient of $\mathrm{NaCl}$ from 0.2 to 0.3 M (2 x $800 \mathrm{ml})$. Elution speed was $150 \mathrm{ml} / \mathrm{h}$, and fractions volume - $15 \mathrm{ml}$. The fractions containing tRNA $^{\text {His }}$ were pooled, precipitated by ethanol and dried. The obtained preparation contained about $30 \%$ of tRNA $^{\text {His }}$.

Further purification of tRNA ${ }^{\text {His }}$ was carried out using HPLC Gold System ("Beckman", USA).

Chromatography on the column of DEAE 5PW. The following buffer solutions were used to perform chromatography: buffer A - $50 \mathrm{mM}$ Tris- $\mathrm{HCl}, \mathrm{pH}$ 7.5, $0.2 \mathrm{M} \mathrm{NaCl}, 10 \mathrm{mM} \mathrm{MgCl}_{2}$ and $10 \%$ isopropanol; buffer B - the same, but with $1 \mathrm{M} \mathrm{NaCl}$. The increase of $\mathrm{NaCl}$ concentration in the chromatography process was in agreement with the curve number 4 , programmed in Gold System. The chromatographic fractions were manually collected, and acceptor activity tRNA ${ }^{\text {His }}$ was assayed. Retention time of tRNA ${ }^{\text {His }}$ on the column was 41 minutes.

Chromatography on the Ultrapore C8 column. The last step of tRNA $^{\text {His }}$ purification was the chromatography on the high-pressure column Ultrapore C8. Buffer A contained $50 \mathrm{mM}$ ammonium acetate, and $10 \mathrm{mM} \mathrm{MgCl}_{2}$, buffer $\mathrm{B}-10 \%$ isopropanol. The gradient was performed in the same way as in case of chromatography on DEAE 5PW column. The results of tRNA ${ }^{\text {His }}$ chromatography on Ultrapore C8 column are shown in Fig.2. On this purification step two isoacceptor RNNA $^{\text {His }}$ were isolated with yield 2.5 and $1.7 \mathrm{mg}$ for $\mathrm{RNA}_{1}{ }^{\text {His }}$ and $\mathrm{RNA}_{2}^{\text {His }}$, respectively. Purity of obtained preparations, checked by electrophoresis in $8 \%$ PAAG with $8 \mathrm{M}$ urea, was not less than $98 \%$. Thus, the method of isolating isoacceptor tRNA ${ }^{\text {His }}$ developed by us, allows obtaining highly purified tRNAs, suitable both for biochemical researches and structural work.

The study of the primary $t R N A_{1}^{\text {His }}$ structure. Before studying the interaction sites of T.thermophilus tRNA $_{1}^{\text {His }}$ with cognate aminoacyl-tRNA synthetase, it was necessary to define the primary structure of this tRNA. For this aim two complementary methods were used: the method of rapid gel-sequencing according to Pitty [15] and the method of specific nuclease 


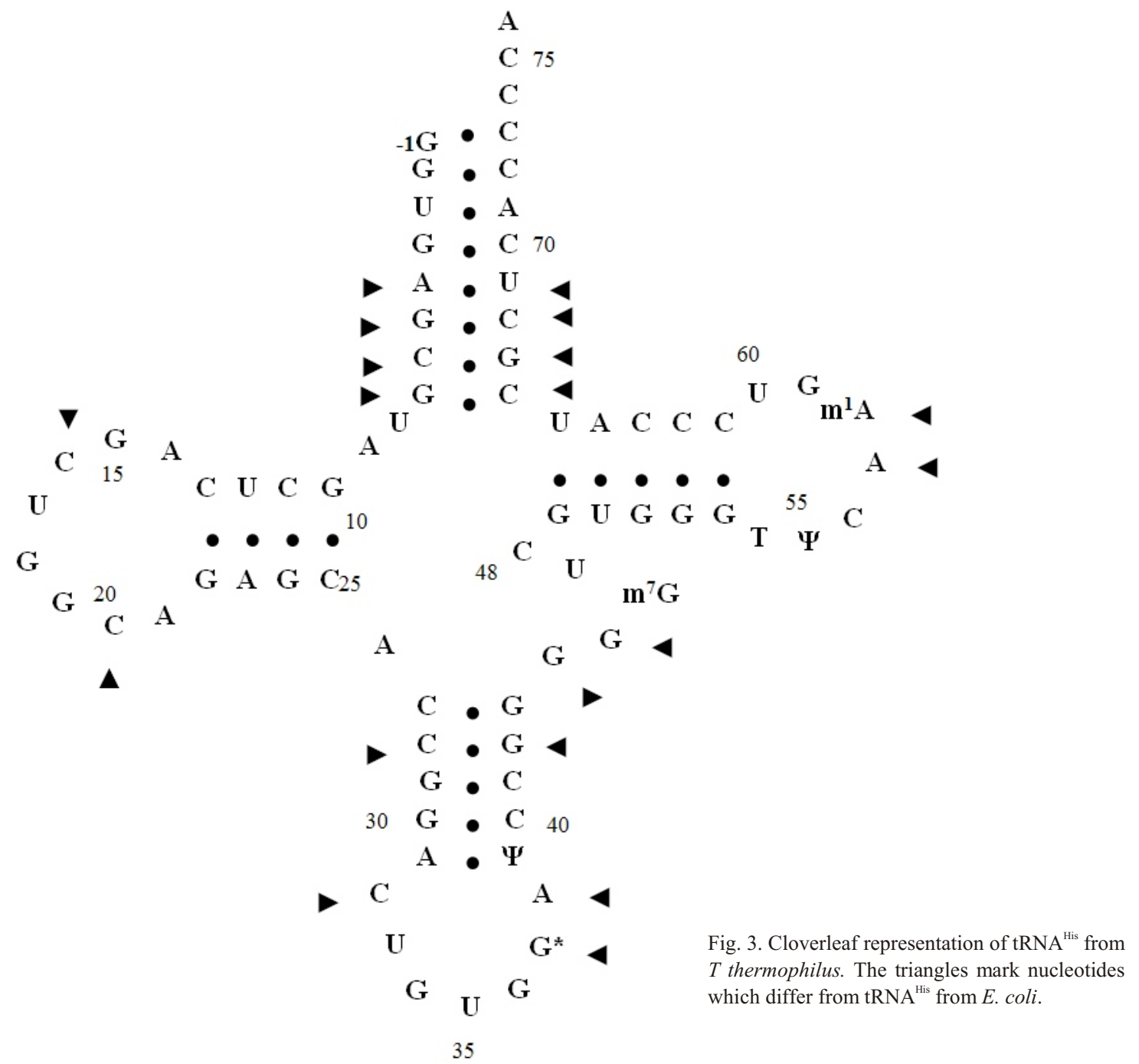

hydrolysis [17]. As a result of conducted researches the complete nucleotide sequence of T.thermophilus tRNA $_{1}^{\text {His }}$ was defined (Fig.3). The comparison of primary structure of the studied $\mathrm{tRNA}_{1}^{\text {His }}$ with the structure of E.coli tRNA $^{\text {His }}$ reveals rather a great similarity between these macromolecules. Differences were found in 23 positions: eight - in the acceptor stem, two - in D-loop, one - between D-stem and anticodon stem, three - in the anticodon stem, three in the anticodon loop, two - in the T-loop (Fig.3). The obtained data of the primary structure of T.thermophilus tRNA ${ }_{1}^{\text {His }}$ show that it has extra G-1 nucleotide on the 5'-end and extra base pair G-1 - C73 in the acceptor stem. These features of tRNA structure are typical for all the known $\mathrm{tRNA}^{\text {His }}$ from prokaryotes [3].
The study of tRNA $A_{1}^{\text {His }}$ interaction with histidyl-tRNA synthetase by the method of chemical modification. The interaction sites of T.thermophilus $\mathrm{tRNA}_{1}{ }^{\text {His }}$ with the cognates synthetase were investigated using the method of chemical modification by ethylnitrosourea. It was established previously that the alkylation of tRNA phosphate groups in the contact sites with the enzyme is complicated [18].

Typical experiment with 3'-labeled $T$. thermophilus $\mathrm{RNA}_{1}^{\mathrm{His}}$ is shown in Figure 4. In the presence of histidyl-tRNA synthetase, several bands are nearly suppressed or are strongly reduced, suggesting that the corresponding phosphate groups are protected by the enzyme from alkylation.

The extent of phosphate alkylation was measured by densitometry of the autoradiograph and relative 


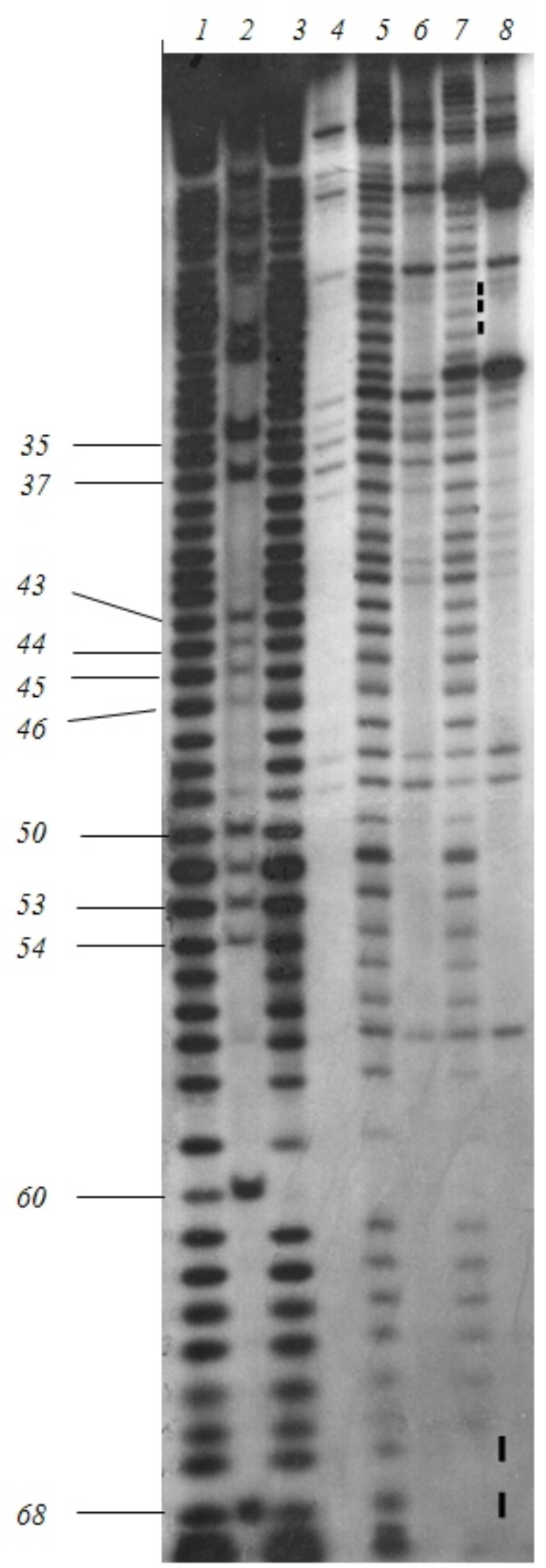

Fig. 4. Separation in 12. \% PAAG of the hydrolysis products of 3'-labeled tRNA $^{\text {His }}$ from T.thermophilus, alkylated by ethylnitrosourea in the conditions, denaturating (I) and stabilizing $(3,5)$ three dimensional tRNA structure, as well as in the presence of histidyl-tRNA synthetase (7); brackets mark the phosphates, the level of modification of which decreases significantly in the presence of histidyl-tRNA synthetase. Corresponding control incubations $(4,6,8)$ were carried out in the absence of ethylnitrosourea; 2 - tRNA $^{\text {His }}$, partially hydrolyzed by $\mathrm{T} 1$ nuclease. The stripes enumeration corresponds to the phosphates in the tRNA ${ }^{\text {His }}$ structure.

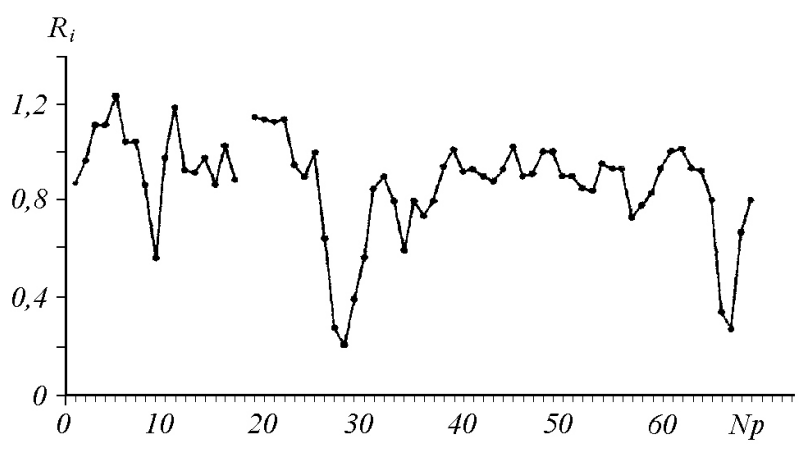

Fig. 5. Relative reactivities of the $\mathrm{RNA}_{1}{ }^{\text {His }}$ from T.thermophilus phosphates at the alkylation by ethylnitrosourea in the presence of histidyl-tRNA synthetase. $R_{i}$ are the ratios between the intensities of the corresponding electrophoretic bands of the tRNAHis alkylation patterns in the presence of the enzyme and free tRNA ${ }^{\text {His }} ; \mathrm{Np}$ - phosphates numbers.

reactivities of phosphates of $\mathrm{RNA}_{1}^{\text {His }}$, which is in the complex with the enzyme, were calculated in comparison with the free tRNA. The data of these experiments are shown in Figure 5 and summarized on cloverleaf representation of tRNA in Figure 6. Presence of histidyl-tRNA synthetase resulted in strong protection ( $40-70 \%$ decrease in band density ) of phosphates in the acceptor stem (67 and 68) and in the anticodon stem $(27,28,29)$. Weaker protection $(20-40$ $\%$ decrease in band density) was observed in the corner of the acceptor and D-stems ( phosphate 8 ) and in the anticodon loop (phosphate 34).

It is worth mentioning that all the defined tRNA ${ }^{\text {His }}$ sites are on one side of three dimensional tRNA structure, namely, on the side of the variable loop, while D-stem is located on the opposite side of the molecule and it does not interact with the enzyme. Thus, obtained data suggest that the interaction of histidyl-tRNA synthetase with the homologous tRNA shows a recognition pattern characteristic of class 11 aminoacyl-tRNA synthetases [20].

A footprinting technique using phosphorotioate-containing RNA transcripts has been applied to identify contacts between E.coli $\mathrm{tRNA}^{\mathrm{His}}$ and its cognate aminoacyl-tRNA synthetase [21]. However, in the mentioned work the protection of some sites which evidently do not coincide with the expected complex structure on the basis of X-ray structural 


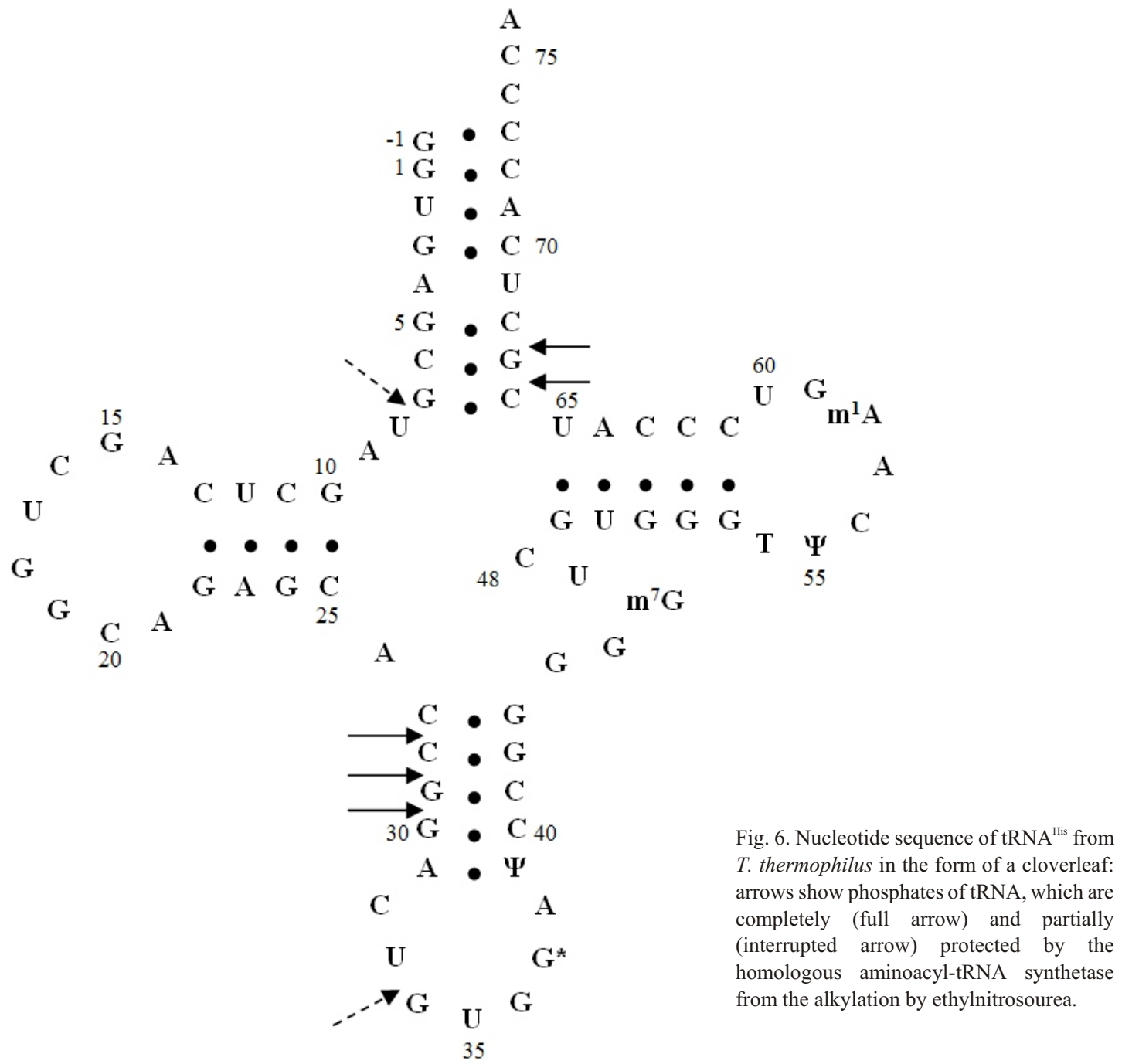

analysis (in particular, sites of D-loop), was revealed besides tRNA sites, which unambiguously interact with the enzyme (e.g. 5'-end of anticodon stem). Obtained artifacts are explained by known disadvantages of the method, used by the authors [22].

The results, presented by us concerning the protection of phosphate acid residues of $\mathrm{tRNA}^{\mathrm{His}}$ from the chemical modification in the presence of homologous synthetase are in good agreement with the previously suggested model of tRNA ${ }^{\text {His }}$ complex with histidyl-tRNA synthetase from T.thermophilus [8]. According to this model tRNA $^{\text {His }}$ interacts with both subunits of the enzyme. Here three main contact areas of tRNA with the protein can be distinguished: tRNA acceptor stem, interacting with the catalytic domain of enzyme; core of tRNA, which has a contact with the catalytic part of another enzyme subunit and finally, anticodon stem, interacting with the C-end of protein domain. We did not obtain the data on reactivity phosphates of tRNA CCA-end due to the known methodical limitations (non-quantitative precipitation of short tRNA fragments by ethanol). At the same time the protection of phosphates 67 and 68 is clearly evident in the acceptor stem (Figure 6e, 6). In the model of tRNA $^{\text {His }}$ complex with $T$. thermophilus histidyl-tRNA synthetase the residue of phosphoric acid 67 interacts with the conservative Arg7 and Arg74 in protein. The importance of this interaction is proved by the mutagenesis date, obtained on the histidyl-tRNA synthetase from E. coli, where the mutation of Arg7 resulted in 50-fold decrease of $\mathrm{K}_{\mathrm{M}}$ for tRNA in the aminoacilation reaction [23]. The phosphate 8 , partially 
protected by histidyl-tRNA synthetase from alkylation, according to the model, should interact with the amino acid residues of the loop 96-98. The largest interaction zone of tRNA ${ }^{\text {His }}$ with the enzyme is the anticodon arm where, according to our biochemical data, the phosphates 28-30 in the anticodon stem and a phosphate 34 in the anticodon interact with the protein. For the interaction with the phosphates of anticodon stem in the complex model, there is a cluster of positively charged amino acids [8], formed by the amino acid residues of the loop $\beta 13-\beta 14$ and the residues, which are included in the composition of alpha-helix $\alpha 14$. To obtain a more complete picture of contacts of $\mathrm{C}$-end domain with anticodon stem $\mathrm{tRNA}^{\mathrm{His}}$, as well as to get clear details of the interaction of these macromolecules on the atomic level it is necessary to obtain crystallographic data of the structure of their complex.

\section{О. И. Гудзера, И. А. Крикливый, А. Д. Яремчук, М. А. Тукало}

Выделение гистидиновой тРНК из Thermus thermophilus и изучение ее первичной структуры и участков взаимодействия с гомологичной аминоацил-тРНК синтетазой

\section{Резюме}

Структура гистидиновых тРНК (тРНК $\left.{ }^{\text {His }}\right)$ отличается от структур тРНК других аминокислотных специфичностей наличием на 5'-конще дополнительного нуклеотида $(G-1)$. Для изучения молекулярного механизма взаимодействия $\mathrm{mPHK}{ }^{\text {His }}$ с гистидил-тPНК синтетзой разработан метод очистки PHK $^{\text {His }}$ из T. thermophilus и изучена первичная структура изоакиепторной формы $т P K_{1}^{\text {His }}$. Индивидуальную mРНК ${ }^{\text {нis }}$ выделяли из суммарной тографии низкого давления на бензоилированной дЭАЭ-иеллюлозе (БД-иеллюлоза) и ДЭАЭ Тоуореагl 650 с жидкостной хроматографией высокого давления на колонках DEAE 5PW и Ultrapore C8. Первичную структуру $\mathrm{PH}_{\mathrm{I}}^{\text {His }}$ из T. thermophilus определяли с использованием методов быстрого гель-секвенирования. Изученная структура отличается от рPHK $^{\text {His }}$ из Escherichia coli по 23 положениям. Участки взаимодействия тPНК, ніs из T. thermophilus с гистидил-тРНК синтетазой исследовали с помошью метода химической модификаиии нитрозоэтилмочевиной. Показано, что гистидил-тРНК синтетаза защищает от алкилирования этилнитрозомочевиной следующие фосфаты тPHK ${ }^{\text {His }}$ : 8?между акиепторным и D-стеблем; 27, 28, 29 ? с 5 '-стороны антикодонового стебля; фосфат 34 в антикодоне и фосфаты 67, 68 с 3'-стороны акиепторного стебля. Все обнаруженные участки тРНК ${ }^{\text {His }}$ локализованы на одной стороне пространственной структуры тРНК? там же, где и вариабельный стебель. D-стебель находится с противоположной стороны и не взаимодействует $c$ ферментом.

Ключевые слова: тРНК, аминоацил-тРНК синтетаза, РНК-белковое узнавание, химическая модификация.

\section{REFERENCES:}

1. Ibba M., Soll D. Aminoacyl-tRNA synthesis // Annu. Rev. Biochem.-2000. 69.-P. 617-650.

2. Cusack S., Yaremchuk A., Tukalo M. tRNA recognition by aminoacyl-tRNA synthetases // The many faces of RNA / Eds D. S. Eggleston, C. D. Prescott, N. D. Pearson.-London: Acad. press, 1998.-P. 55-65.

3. Steinberg S., Misch A ., Sprinzl M. Compilation of tRNA sequences and sequences of tRNA genes // Nucl. Acids Res.-1993.—21.—P. 3011-3015.

4. Himeno H., Hasegawa T., Ueda T., Watanabe K., Miura K., Shimizu $M$. Role of the extra G-C pair at the end of the acceptor stem of the tRNA $^{\text {His }}$ in aminoacylation // Nucl. Acids Res.-1989.-17.-P 7855-7863.

5. Nameki N., Asahara H., Shimizu M., Okada N., Himeno H. Identity elements of Saccharomyces cerevisiae tRNA ${ }^{\text {His }} / /$ Nucl. Acids Res.-1995.-23.-P. 389-394.

6. Arnez J. G., Harris D. S., Mitschler A., Rees B., Francklin C. S., Moras $D$. Crystal structure of histidyl-tRNA synthetase from Escherichia coli complexed with histidyl-adenylate // EMBO J.-1995.-14.-P. 4143-4155.

7. Yaremchuk A., Cusack S., Aberg A., Gudzera O., Krikliviy I., Tukalo M. Crystallization of Thermus thermophilus histidyl-tRNA synthetase and its complex with tRNA ${ }^{\text {His }} / /$ Proteins: structure, function and genetics.-1995.-22.-P. 426-428.

8. Aberg A., Yaremchuk A., Tukalo M., Rasmussen B., Cusack S. Crystall structure analysis of the activation of histidine by Thermus thermophilus histidyl-tRNA synthetase Biochemistry.-1997.-36.-P. 3084-3094.

9. Yaremchuk A., Tukalo M., Grotli M., Cusack S. A succession of substrate induced conformational changes ensures the amino acid specificity of Thermus thermophilus prolyl-tRNA synthetase: comparison with histidyl-tRNA synthetase // J. Mol. Biol.-2001.-309.-P. 989-1002.

10. Brungraber E. F. A simplied procedure for the preparation of «soluble» RNA from rat liver // Biochem. and Biophys. Res. Communs.-1962.-8.-P. 1-3.

11. Bruce A. G., Uhlenbeck $O$. S. Reactions at the termini of the tRNA with T4 RNA ligase // Nucl. Acids Res.-1978.-5.-P 3665-3677.

12. Silberklang M., Gillum A. M., Raj Bhandary U. L. The use nuclease P1 in sequence analysis of end group labeled tRNA // Nucl. Acids Res.-1977.-4.-P. 4091-4108.

13. Rether B., Bonnet J., Ebel J. P. Studies on tRNA nucleotidyltransferase from baker's yeast. 1. Purification of the enzyme. Protection against thermal inactivation and inhibition by several substrates // Eur. J. Biochem. - 1974. - 50.-P. 281-288.

14. Vlasov V. V., Giege R., Ebel J. P. Tertiary structure of tRNA in solution monitored phosphodiester modification with ethylnitrosourea // Eur. J. Biochem.-1981.-119.-P. 51-59.

15. Peattie D. A. Direct chemical method for sequencing RNA // Proc. Nat. Acad. Sci. USA.—1979.-76.-P. 1760-1764.

16. Lockard R. E., Alzner-Debveerd B., Heckman J. E., Mac-Gee J., Tabor M. W., Raj Bhandary U. L. Sequence analysis of $5,\left\{{ }^{32} \mathrm{P}\right\}$ labeled mRNA and tRNA using polyacrylamide gel electrophoresis // Nucl. Acids Res.-1978.-5.-P. 37-56.

17. Donis-Keller H., Maxam A. M., Gilbert W. Mapping adenines, guanosines and pyrimidines in RNA // Nucl. Acids Res.-1977.-4.-P. 2527-2538.

18. Vlasov V. V., Korn D., Giege P., Ebel J.-P. Protection of phosphodiester bonds in yeast tRNA ${ }^{\text {val }}$ by its cognate aminoacyl-tRNA synthetase against alkilation by ethylnitrosourea // FEBS Lett.-1981.-123.-P. 277-281.

19. Остерман Л. А. Хроматография белков и нуклеиновых кислот.-М.: Наука, 1985.—536 с. 
20. Arnez J. G., Moras D. Structural and functional consideration of the aminoacylation reaction // TIBS. - 1997.-22.-P. 211-216.

21. Bovee M. L., Yan W., Sproat B. S., Franclyn C. S. tRNA discrimination at the binding step by a class II aminoacyl-tRNA synthetase // Biochemistry.-1999.-38.-P. 13725-13735.

22. Rudinger J., Puglisi J. D., Putz J., Schatz D., Eckstein F., Florentz C., Giege R. Determinant nucleotides of yeast tRNA(Asp) interact directly with aspartyl-tRNA synthetase // Proc. Nat. Acad. Sci. USA.-1992. 89.-P. 5882-5886.

23. Hawko S. A., Franclyn C. S. Covariation of a specificity-determining structural motif in an aminoacyl-tRNA synthetase and a tRNA identity element // Biochemistry.-2001._40.-P. 1930-1936.

Надійшла до редакціі 08.02 .06 